\title{
SUSTAINABLE TOURISM IMPLEMENTATION AND CHALLENGES FACED BY HOTELIERS THROUGH TOURISM PRACTICES IN PRAWIROTAMAN TOURIST VILLAGE, YOGYAKARTA SPECIAL REGION PROVINCE
}

\author{
HASTUTI*1 AND ASSRIYANI $^{2}$ \\ ${ }^{I}$ Geography Education, Faculty of Social Science, ${ }^{2}$ Postgraduate Geography Education, Yogyakarta State University, \\ Yogyakarta, Indonesia.
}

*Corresponding author: hastuti@uny.ac.id

Submitted final draft: 8 June 2020 Accepted: 13 June 2020

http://doi.org/10.46754/jssm.2021.01.013

\begin{abstract}
Hotels are one of the primary tourism industries which have a major impact on the environment and society. The importance of this role makes hoteliers need to adopt sustainable tourism practices in their operations. This research aims to determine how far the implementation of sustainable tourism by hoteliers in Prawirotaman, as well as various challenges, faced. Three hotels that are considered representative are used as samples based on purposive sampling. Data collection was obtained from interviews, analysis of previous research work, and observations to be processed by qualitative methods. Fifteen sustainable tourism practices have been found. There is seven best practice that has been generally applied by hoteliers, they use eco-friendly building materials, energy-saving culture, green space and water bodies availability, recruit local people for jobs, buy from local suppliers, economic cooperation in services sectors with the local community, adoption of the local culture at the interior and exterior design. The main challenges in this practice are the problem of groundwater management and operational costs. Connecting with these problems, it is necessary to have the support and concrete action from the government, one of them is by repairing pipes of local water supply company (PDAM) to avoid the crisis of groundwater decline.
\end{abstract}

Keywords: Sustainable tourism, tourism practices, hotel industry.

\section{Introduction}

Tourism is one of the fastest-growing economic sectors in the world in recent decades (Glaesser et al., 2017). United Nations World Tourism Organization (2019) showed the number of international tourist arrivals increased from 25 million in 1950 to 1.4 billion in 2018, with an average growth rate of 5-6\% every year. The high market growth potential makes the tourism sector seen as the largest employer of some local communities and the main source of foreign exchange income for countries in the world (Hall \& Richards, 2003; Mbaiwa, 2003; Habibullah et al., 2019). Apart from the many benefits in the socio-economic sector, the high potential for growth in this sector also provides various negative impacts on the environment. Experts assume that tourism activities can cause environmental degradation through fragmentation, destruction of habitat, competition for natural resources, import of invasive species, tourist's trekking, animal exploitation, transportation emissions, and construction of hotels that have an impact on the conversion of green land and energy use in high numbers (Archer et al., 2005; Stefanica \& Butnaru, 2015). Management of tourism that is too dependent on market interests, can also further lead to cultural degradation, customs, and lifestyles of local communities (Cortes et al., 2009). Related to this problem, the development of sustainable concepts is seen as one of the efforts that need to be prioritized by all tourism industry players, to support environment-based tourism and the community.

The concept of sustainability was first discussed in 1980 through the paradigm of environmentalism. At that time, experts began to understand that population growth and the industrial sector will continue to have an impact on the environmental damage that can't be restored (Bramwell \& Lane, 
1993). The basic idea of sustainability is the preservation of the environment and society in the global socioeconomic system, intending to maintain prosperity in the long term (Costanza \& Patten, 1995; Kuhlman \& Farrington, 2010). Sustainability is one of the economic development paradigms that highlights the phenomenon of the scarcity of resources, this paradigm requires the creation of a type of artificial environment that can meet human needs today without limiting or reducing the ability of future generations to meet their own needs (Owen et al., 1992; Pearce \& Vanegas, 2002; Kuhlman \& Farrington, 2010).

Goodman (2000) argues, sustainability is seen as a framework that can be adopted by various sectors, one of which is tourism. Bramwell and Lane (1993) defines sustainable tourism as a positive approach to reduce tension and various negative impacts created by the complex interactions between the tourism industry players with the environment and the local community, without compromising visitor satisfaction. Sustainable tourism planning and management need to be guided by a balance of environmental, economic, and socio-cultural aspects to realize longterm success (Niedziolka, 2012; Swarbooke \& Page, 2012; Siew et al., 2017; Taechasriprasert et al., 2019). Synergy and complimentary relationships between these aspects must always be considered to build human responsibility to promote and adopt the concept of sustainability, starting from individuals, local, national, and international communities (Mensah, 2019). Liu (2003) mentions four important issues in the development of sustainable tourism which includes: (a) balanced perspectives about the concept of sustainability; (b) encouragement to realize practical and theoretical steps; (c) understanding of the characteristics and dynamics of tourism; and (4) collaboration and synergy between various communities through an interdisciplinary approach. Research by Setiawan et al. (2017) in Karimunjawa, showed that the sustainable tourism approach proved effective as one form of adaptation to the changing environment and the global economy.
The hotels' existence as a tourism element that uses a lot of energy and resources in its management, is considered as one of the sectors that have a great responsibility in carrying out sustainable tourism practices (Bader, 2005; Erdogan \& Baris, 2007). But in reality, there are still many hotels that are not aware yet of this role and are only oriented by commercial purposes. The number of unplanned construction of accommodation facilities has resulted in various activities that damage the environment, such as draining swamps and mangrove forests to open resort areas, exploitation of groundwater to meet tourist needs, use of chemicals and hard to decompose materials for operational needs, and polluted rivers and the sea by hotel waste that is not treated in advance (Archer et al., 2005; Kementerian Pariwisata dan Ekonomi Kreatif Republik Indonesia \& ILO, 2010). Therefore, hotels need to adopt the principles of sustainable tourism, to carry out their role in environmental conservation efforts and minimize the negative impacts that can be caused by various tourism activities (Habibullah et al., 2019). Adam et al. (2019) reported that the development of a tourism area has a significant effect on the quality of life of local communities, that's why in this case sustainable tourism is not only focused on environmental conservation but also on empowering communities around the region (Wijesundara, 2017).

In this decade, hotels in various parts of the world have begun to understand their role in reducing the negative impact of tourism activities on the environment and society. The hoteliers began to show their concern and turn to the approach of sustainable tourism. This statement is reinforced by the results of research by many researchers in different countries. Wijesundara's research (2017) has shown a positive awareness movement by hotel operators in Sri Lanka through the adoption of various sustainable tourism practices in their operations. The research results of Mihalic et al. (2011) present a finding that the hotel industry in Slovenia this decade began to develop a Hotel Sustainability Business Model (HSBM) oriented towards visitor satisfaction, 
education on environmental conservation, and the power of adaptation in the face of change. Research Kasimu et al. (2012) reported that some hotels in Lembah Klang, Malaysia, have sought to address environmental degradation through sustainable tourism practices, one of which is through energy savings based on an Environmental Management System (EMS).

Indonesia is the fifth international tourist destination in Southeast Asia, with the number of foreign tourist arrivals reaching 13.4 million in 2018 (UNWTO, 2019). One of the main tourist destinations in Indonesia is Yogyakarta. Dinas Pariwisata Kota Yogyakarta (the official local tourism office) reported, Yogyakarta has a tourist visit rate of 4.1 million in 2018, which is predicted to continue to grow every year (Figure 1). Discussing tourism in Yogyakarta, the existence of the Prawirotaman area known as a tourist village has never been unnoticed. The area which is located in the Brontokusuman Village, Mergangsan District, has long been a destination for tourists, especially foreign tourists (Timothy, 1999). Wirakusuma's research results (2014) showed that several factors that influenced tourist attraction to the Prawirotaman area were diversity of accommodation types at affordable prices, strong historical and cultural values, the availability of hangout, and culinary facilities, comfortable and relaxed atmosphere, and ease of accessibility.

Research by Ardhiansyah et al. (2019) showed until now there has been significant physical development in Prawirotaman, especially hotels and commercial business. However, this development wasn't followed by an adequate arrangement of green open space, which impacts several environmental problems such as groundwater level decline. Based on observations, in addition to environmental problems, several other problems were also complained about by residents. Local people gave their opinion, that the rapid tourism-based physical development in the Prawirotaman area has an impact on the loss of characteristics of the area which used to be known as "Kampung Batik". Now only a few residents still survive doing business as batik craftsmen. Indirectly this has an impact on the problem of increasing local people's need for employment. Prawirotaman has 5-star hotels, 43 non-star hotels, and provides accommodation, which has an important role in making sustainable tourism concepts in Yogyakarta, both local and national (Badan Pusat Statistik, 2018). These hotels need to be responsible for managing the balance of environmental, social, and economic aspects in Prawirotaman. However, the implementation of

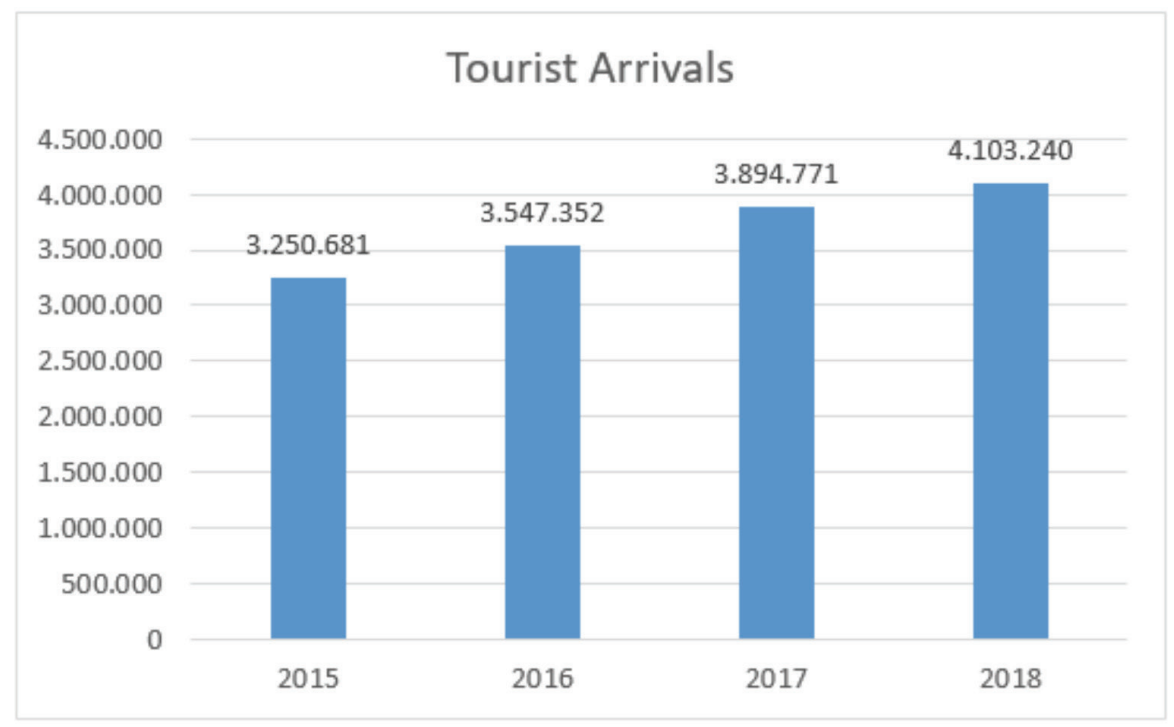

Figure 1: Number of tourist arrivals in Yogyakarta 
sustainable tourism has never escaped various challenges.

\section{Materials and Methods}

This research uses a descriptive qualitative method with an ecological approach and case studies. The results of this study will be explained descriptively based on the researchers' interpretation of the findings data in the field. The ecological approach is used as one of the characteristics of geography research, with an emphasis on environmental and communitybased sustainability practices. The case study approach is used because of its ability to explore a phenomenon in-depth and thoroughly so that understanding and information that are the objectives of the research can be obtained optimally.

The location of this research is the Prawirotaman Tourist Village area, which is located in Brontokusuman Village, Mergangsan, Yogyakarta City (Figure 2). Based on environmental characteristics, this area is centered around Prawirotaman Street. The population of this study is the entire accommodation business sector in the study site consisting of star hotels, non-star hotels, homestays, and other similar businesses. Three hotels that are considered representative are used as samples based on purposive sampling.

In this study, triangulation of data collection methods and data sources was used (Figure 3). The main data collection method is in-depth interviews, while the analysis of previous research work and observations is used as a comparison. Interviews about sustainable tourism practices at each hotel are carried out until the information obtained from the speakers is deemed saturated. 23 respondents were selected to be interviewed about their views and perspectives on how much the concept of sustainable tourism has been

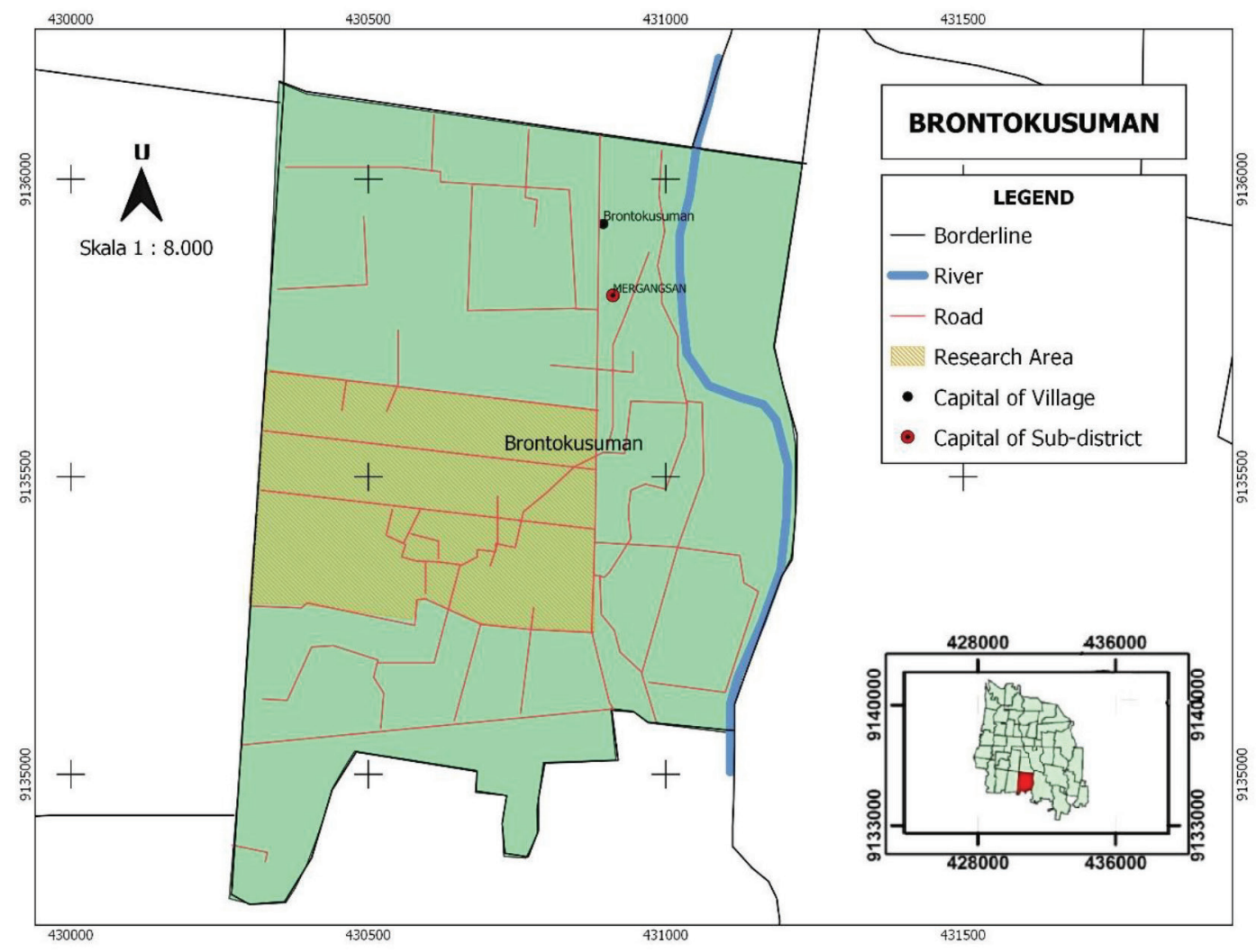

Figure 2: Research area 


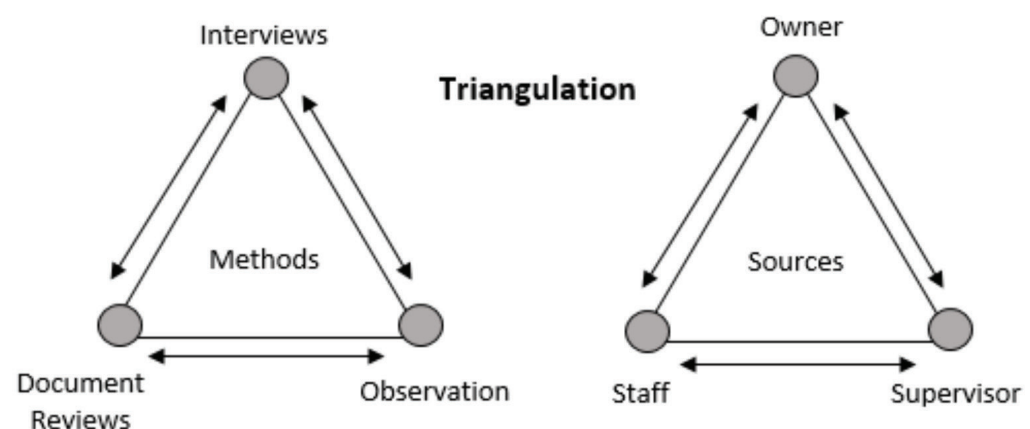

Figure 3: Research's triangulation

implemented in their hotel, and what challenges they found during the process. Respondents as data sources consist of hotel owners or managers, supervisors, and staff. Hotel owners or managers are the main respondents in the study because of their position as policymakers and are considered to understand hotel facilities and management in detail, while supervisors and hotel staff are informants used to cross-check or test the validity of information collected through triangulation of data sources.

\section{Result and Discussion}

Prawirotaman Tourist Village is one of the main accommodation destinations for tourists in Yogyakarta, which provides various types of hotels at affordable prices. From the 1970s until now, more than 80 hotels, both star, and nonstar have been operating in the Prawirotaman area. Each hotel offers a different concept from one another, where the selection of this concept will usually be based on market or trends. One of the development trends that are currently warm is the concept of 'sustainability', in this case, it is more specific to sustainable tourism. Based on observations that have been made, several hotels in this location have adopted the concept of sustainable tourism, which is based on environmental, economic, and socio-cultural concerns in their management practices.

This study took qualitative data on three hotels in the Prawirotaman area through indepth interviews, observation, and analysis of previous research work. Through data collection and analysis that has been done, it was found that fifteen sustainable tourism practices have been applied by the hotel business in the Prawirotaman Tourist Village. The fifteen practices include eight concerns in the environmental field, three concerns in the economic field of society, and four concerns in the socio-cultural field.

Table 1 shows the forms of sustainable tourism practices carried out by three hospitality businesses in the Prawirotaman area. This finding will measure the extent to which the concept of sustainable tourism has been adopted by each hotelier. Based on the comparison that can be seen in the table, Hotel A shows the highest sustainable tourism adoption score (Score: 14), followed by Hotel B (Score: 9) and Hotel C (Score: 7). Judging from the number of $\mathrm{N}$ values (number of hotels adopting), seven sustainable tourism practices have been generally applied by all research samples with a percentage of $100 \%$. The seven best practices adoption are used eco-friendly building materials, energysaving culture, green space, and water bodies availability, recruit local people for jobs, buy from local suppliers, economic cooperation in services sectors with the local community, adoption of the local culture at the interior and exterior design.

First, use eco-friendly building materials. This confirms that the hotel manager has realized the importance of choosing building materials that can reflect nature, are easily decomposed, and able to absorb sunlight properly to reduce the air temperature in the surrounding environment. In addition to supporting the concept of nature and eco-friendly, the respondents considered 
Table 1: Sustainable tourism practices by hoteliers

\begin{tabular}{|c|c|c|c|c|c|c|}
\hline No. & Sustainable Tourism Practices & $\begin{array}{c}\text { Hotel } \\
\text { A }\end{array}$ & $\begin{array}{c}\text { Hotel } \\
\text { B }\end{array}$ & $\begin{array}{c}\text { Hotel } \\
\text { C }\end{array}$ & $\mathbf{N}$ & $\%$ \\
\hline \multirow[t]{9}{*}{1.} & Environmental & & & & & \\
\hline & Use eco-friendly building materials & 1 & 1 & 1 & 3 & 100 \\
\hline & Use of renewable energy & 1 & 0 & 0 & 1 & 33 \\
\hline & Energy-saving culture & 1 & 1 & 1 & 3 & 100 \\
\hline & d. Water resource management & 1 & 1 & 0 & 2 & 66 \\
\hline & Green space and water bodies & 1 & 1 & 1 & 3 & 100 \\
\hline & Waste management & 1 & 0 & 0 & 1 & 33 \\
\hline & g. Grow food plants & 1 & 0 & 0 & 1 & 33 \\
\hline & $\begin{array}{l}\text { h. Reducing plastics in operational } \\
\text { activities }\end{array}$ & 0 & 0 & 1 & 1 & 33 \\
\hline \multirow[t]{4}{*}{2.} & Economic & & & & & \\
\hline & a. $\quad$ Recruit local people for jobs & 1 & 1 & 1 & 3 & 100 \\
\hline & b. $\quad$ Buy from local suppliers & 1 & 1 & 1 & 3 & 100 \\
\hline & $\begin{array}{l}\text { E. Economic cooperation in services } \\
\text { sectors with the local community }\end{array}$ & 1 & 1 & 1 & 3 & 100 \\
\hline \multirow[t]{6}{*}{3.} & Socio-Cultural & & & & & \\
\hline & $\begin{array}{l}\text { a. Adoption of the local culture at } \\
\text { the interior and exterior design }\end{array}$ & 1 & 1 & 1 & 3 & 100 \\
\hline & b. Access to local culture & 1 & 1 & 0 & 2 & 66 \\
\hline & c. Serving traditional local cuisine & 1 & 1 & 0 & 2 & 66 \\
\hline & d. Disability service & 1 & 0 & 0 & 1 & 33 \\
\hline & Score & 14 & 9 & 7 & & \\
\hline
\end{tabular}

Source: Primary Data, 2019

that these materials could make the hotel cooler to provide comfort for visitors. Types of ecofriendly building materials that are widely used include wood, brick, natural stone, local ceramics, rattan, and bamboo. Respondents from hotel A even stated that from the very beginning their hotel carried the concept of nature, so as much as possible their buildings must be ecofriendly, not only in terms of building materials but also in terms of architecture. In contrast to star hotels in general who are competing to make tall buildings, hotel $\mathrm{A}$ is more oriented towards building in a landscape or to the side to reduce the reflection of solar radiation reflection and thermal effects on the environment.
In general, hoteliers' understanding of the importance of choosing environmentally friendly building materials is good enough. The hotel management understands that the function of the material they have chosen does not only have an impact on the environment. It also functions to build or strengthen certain concepts offered by hotels, and provide special comfort for visitors.

Second, energy-saving culture. The majority of respondents stated that their hotel had paid attention to the mission of using energy wisely. These hotels have switched to using lighting systems and low energy electronic devices based on LED (Light Emitting Diode) technology. The 
use of $\mathrm{AC}$ is done as wisely as possible, in hotel A and hotel B for example, AC is only used for guest rooms, while other areas such as lobby, restaurants, gyms, and relaxing places do not use $\mathrm{AC}$ at all. Even in hotel $\mathrm{C}$, only a few rooms are equipped with air conditioning, and the other rooms are mostly facilitated by a fan. Not only electricity but hotel B also indirectly contributes to fuel oil savings through the cycling culture of employees. Respondents agreed that the various measures, in addition to saving energy also helped reduce hotel operating costs, so they needed to be proclaimed.

The results showed that hotel managers and staff have collaborated and synergized well in fostering an energy-saving culture in the workplace. Most of the staff showed their agreement on hotel management policies related to energy-saving culture. Besides, the hotel positively invites and facilitates guests to participate in this effort, for example by providing bicycles as an environmentally friendly means of transportation, and encouraging guests to turn off lights and electronic devices when they are not in the room.

Third, green space and water bodies availability. The hotel manager has realized the importance of providing vegetation areas and water bodies in regulating the microclimate. Water and vegetation have a good ability to absorb sunlight so that its presence can reduce surface temperature. Vegetation also has other ecological functions such as shade, windbreaker, storage of water reserves, and oxygen producers. All respondents agreed that the existence of green areas and water bodies is vital and has proven to provide many benefits, especially for the hotel environment directly. Some respondents stated, in addition to maintaining the balance of nature, the presence of green areas and water bodies also served to improve the aesthetic value of hotels, for example by providing gardens and ponds.

The provision of green areas and water bodies, especially in hotel A, is closely related to the adoption of other sustainable tourism practices, there are water resource management and growing food plants. The garden which is made as a green area is not only covered with ornamental plants and shade trees but also is grown with a variety of food plants that can be consumed by guests and hotel staff. Concerning water management issues, the majority of respondents expressed the same complaint, that their hotel could not get water from the Perusahaan Daerah Air Minum (PDAM), a local water supply company, because of constraints in the pipeline damage in the southern part of Yogyakarta City. So to meet the needs of hotel water, the hoteliers must use groundwater.

Fourth, recruit local people for jobs. All three hotels stated that they contributed to reducing unemployment in the local community through the recruitment of workers. Hotels A and B even provide training or short training for prospective workers who do not have experience. In addition to receptionists who have special requirements, around $50-70 \%$ of the employees of these hotels are residents. While the rest are migrants who are recruited from outside the area such as Magelang, Temanggung, and Tawangmangu, who sleep every day in the hotel area. These conditions indicate the concern of hoteliers for the economic welfare of local people. The hotel management has been well aware of their role in providing employment, without complicating the surrounding community with various complex requirements. The hotel owners massively agreed that the honesty, friendliness, and hard work of the local community in serving guests was valued more than their educational background.

Fifth, buy from local suppliers. Apart from recruiting workers, each hotel also pays more attention to the welfare of the local community by buying their operational needs from local suppliers and craftsmen. Respondents stated that hotel food needs were mostly bought from traders in the Prawirotaman market, amenities and toiletries were purchased from suppliers in the Bantul area, garden and fish ponds were purchased at pasty markets, while furniture and accessories for light decoration such as paintings, statues and batik cloth purchased directly from the craftsmen in the Prawirotaman 
area. Indirectly, this practice is one form of adoption of sustainable tourism to improve the quality of life of local people.

Sixth, economic cooperation in services sectors with the local community. Most respondents stated that their hotel had collaborated with several service business sectors managed by the local community. This collaboration is carried out to create synergy between tourism businesses in the Prawirotaman area, to provide maximum service to tourists. Some service businesses that have collaborated with these hotels for example travel agencies, pedicab drivers, and vehicle rentals.

Seventh, adoption of the local culture at the interior and exterior design. Respondents massively agreed that their hotel had used interiors and exteriors that represented local cultural characteristics, and this practice was well received by tourists, especially foreign tourists. In general, the three hotels together carry a classic ethnic design that is thick with the use of typical Javanese ornaments. The adoption of the design is seen from 'pendopo' shaped buildings used as public areas, the use of 'gebyok' (wooden partitions) as entrances, the use of traditional containers such as woven bamboo, earthenware, and banana leaves in food serving, various wooden furniture with Javanese carving accents, batik motif murals in hotel guest rooms, selection of home sets (pillowcases, blankets, curtains, tablecloths, etc.) with batik motifs, puppet paintings as decorations, and many more. This shows that the hotel manager has given a positive response to the preservation of local culture, and further plays a role in presenting aesthetic values to be enjoyed by hotel guests.

From all the findings in the field, there are always some best practices that have more proportions than others. So, in addition to the seven best practices above, there are eight findings of other sustainable tourism practices that have been successfully implemented even though not all sample hotels have adopted them, they are the use of renewable energy, water resource management, waste management, grow food plants, reducing plastics in operational activities, access to local culture, serving traditional local cuisine, and disability service. Certain forms of practice are even only found in one hotel so that it can be a characteristic that distinguishes the hotel from other hotels in the Prawirotaman Tourist Village.

\section{Sustainable Tourism Practices by Hotel A}

Hotel A is one of the hotels in the Prawirotaman area that has been operating since 2012. As a relatively new hotel, this hotel has shown concern for the environment by adopting the concept of eco-friendly and green hotels. The hotel owner understands his role and responsibilities in reducing the environmental, economic, and socio-cultural impacts of the business activities he runs. Blending elements of nature, ethnicity, and oriented towards empowering local people to make this hotel one of the hotels with the adoption of the best sustainable tourism practices in Prawirotaman Tourist Village. The results showed that as many as fourteen sustainable tourism practices were found in hotel A. The fourteen practices consisted of seven practices in the environmental field, three practices in the economic field, and four practices in the socialcultural field.

Table 2 shows in more detail the implementation of sustainable tourism practices carried out by hotel A. Concern for the environment is found in seven practices. First, the concept of the building is made by choosing eco-friendly materials such as wood, brick, and natural stone, then for development carried out horizontally on a very large land, so as not to interfere with wind movement. Secondly, the concept of buildings in public areas is made semi-open to get maximum air and natural light, especially during the daytime. This second practice is also supported by the selection of lowenergy electronic devices (LED technology) and restrictions on the use of energy wisely. Third, start using solar panels as a renewable energy source for water heating systems in all hotel guest rooms. Fourth, providing green areas and water surfaces in every corner of the hotel to 
Table 2: Implementation of sustainable tourism practices in Hotel A

\begin{tabular}{|c|c|}
\hline No. & Environmental \\
\hline 1. & $\begin{array}{l}\text { Use eco-friendly building } \\
\text { materials: }\end{array}$ \\
\hline & $\begin{array}{l}\text { Using many eco-friendly } \\
\text { building materials such as } \\
\text { wood, natural stone, local } \\
\text { ceramics, and bricks. }\end{array}$ \\
\hline
\end{tabular}

2. Energy-saving culture:
a. The use of LED lights and TVs.
b. AC is only used for guest rooms.

c. Minimize the use of light during the day by maximizing the entry of natural light.

\section{Buy from local suppliers:}

a. Buying kitchen supplies in the Prawirotaman market

b. Buy hotel operational products from local suppliers in the area of Yogyakarta.
Socio-Cultural

Adoption of the local culture at the interior and exterior design:

a. Adopting a Javanese interior through the use of wood material as the main element.

b. Presenting many Javanese ornaments at decoration.
Access to local culture:

a. Gives guests access to listen to gamelan music every day

b. Provide services to guests to learn about gamelan and batik culture.
3. Use of renewable energy:

a. The use of solar panels for solar water heating systems.
Economic cooperation in services sectors with the local community:

a. In collaboration with pedicab services, several tour and travel services, and batik artisans in the local area.
4. Green space and water bodies:
a. Provision more green areas with a proportion of $>30 \%$ of hotel areas.
b. Provision of three fish ponds and two swimming pools as water bodies.

\section{Disability service:}

a. Provision special lane and toilets for a wheelchair user
Serving traditional local cuisine:

a. Serve a variety of traditional Yogyakarta food as a breakfast menu and afternoon snacks.

5. Water resource management:
a. Provide more than one
hundred biopori holes and
three absorption wells

6. Waste management:
a. Composting of organic waste
b. Waste sorting culture

7. Grow food plants:

a. Grow a variety of fruit plants for the consumption of staff and hotel guests. 
regulate the comfort of the microclimate. Fifth, the creation of hundreds of biopori holes and three infiltration wells to store additional water in various points of open land. Sixth, minimizing solid waste disposal through composting organic waste and doing simple waste sorting based on the type (organic waste, non-organic waste, hazardous and toxic waste). Seventh, growing various fruits such as jackfruit, mango, guava, and matoa for direct consumption by the staff and served to hotel guests at breakfast time.

Concern for empowerment and local community income is found in three practices. First, recruit local people for jobs. Hotel A has a total of twenty-two staff who come from the local community, they work as a laundryman, housekeeping, gardener, and kitchen staff. This local staff is recruited regardless of educational background, and in advance are given short training by expert staff for two to four weeks. Second, buying from local suppliers. Most food supplies and daily necessities are purchased from local traders in Prawirotaman Market, which is located is near the hotel, other necessities such as toiletries and amenities are taken from Piyungan, while furniture and home sets are purchased from craftsmen at Beringharjo Market or shops around Adisucipto street. Third, economic cooperation in services sectors with the local community, especially the Prawirotaman pedicab community, local batik artisans, and tour and travel businesses run by the local community.

Concern for the socio-cultural aspects is found in four practices. Three practices related to the preservation of local culture, including the adoption of local culture in the design of buildings, providing access for hotel guests to enjoy and learn the local culture, as well as serving traditional dishes of the local area. One characteristic of hotel A in this practice is the adoption of Javanese interior, exterior, and decoration which is very thick through (a) using wood as the main element, for example as a roof, pillars, partitions, doors, and windows, as well as various furniture such as chairs, cupboards, tables, and beds; (b) use the 'pendopo' model as a lobby and restaurant building concept, complete with the use of 'gebyok' as the hotel entrance; (c) presenting many Javanese ornaments through furniture carving accents, wall carvings, and selection of batik motifs on the home setting; and (d) use sculptures and paintings themed 'wayang' characters and local wisdom as ethnic decorations. Hotel A also provides services for hotel guests who are interested in learning gamelan and batik. Besides that, Hotel A also serves traditional Yogyakarta dishes for breakfast and traditional snacks with coffee or tea in the afternoon. One last practice relates to services for guests with special needs (disability service), through the provision of special lanes and toilets for wheelchair users.

\section{Sustainable Tourism Practices by Hotel B}

Hotel B is one of the oldest hotels that spearheaded the Prawirotaman area as a tourist accommodation. The hotel began operating in 1982 and continues to expand and improve to this day. Carrying the concept of a guesthouse to bring tourists closer to the local community, Hotel B has thirty-five rooms for rent with various types and rates. The results showed that as many as ten sustainable tourism practices were found in hotel $\mathrm{B}$. The ten practices consisted of four practices in the environmental field, three practices in the economic field, and three practices in the social-cultural field.

Table 3 shows the adoption of sustainable tourism practices carried out by hotels B. Concern for the environment is found in four practices. First, the concept of the building is made by choosing eco-friendly materials such as wood, brick, and natural stone, renovation is often done by utilizing old or unused materials that are reused by repairing them first. Second, building and implementing an energy-saving culture through the use of low-energy lamps and TVs, providing fans in each guest room as an alternative to reducing room costs and $\mathrm{AC}$ usage, and promoting eco-friendly movements by cycling for guests and staff. To support this movement, the hotel provides several bicycle units that can be used freely by hotel staff and 
Table 3: Implementation of sustainable tourism practices in Hotel B

\begin{tabular}{|c|c|c|c|}
\hline No. & Environmental & Economic & Socio-Cultural \\
\hline 1. & $\begin{array}{l}\text { Use eco-friendly building } \\
\text { materials: } \\
\text { a. Using wood, brick, and } \\
\text { natural stone as main } \\
\text { eco-friendly building } \\
\text { materials. } \\
\text { b. } \\
\begin{array}{l}\text { Reuse old and unused } \\
\text { material for renovating } \\
\text { the building }\end{array}\end{array}$ & $\begin{array}{l}\text { Recruit local people for jobs: } \\
\text { a. Recruiting local peoples } \\
\text { to work as housekeeping } \\
\text { or room boy, laundryman, } \\
\text { and kitchen staff. }\end{array}$ & $\begin{array}{l}\text { Adoption of the local culture } \\
\text { at the interior and exterior } \\
\text { design: } \\
\text { a. Adopting a Javanese } \\
\text { interior through the } \\
\text { use of wood material } \\
\text { as the main element. } \\
\text { b. Presenting many } \\
\text { Javanese ornaments at } \\
\text { decoration. }\end{array}$ \\
\hline 2. & $\begin{array}{l}\text { Energy-saving culture: } \\
\text { a. The use of LED lights } \\
\text { and TVs. } \\
\text { b. Provide a fan in each } \\
\text { guest room as an option } \\
\text { to reduce the use of AC. } \\
\text { c. Promote eco-friendly } \\
\text { movements by cycling for } \\
\text { guests and staff. }\end{array}$ & 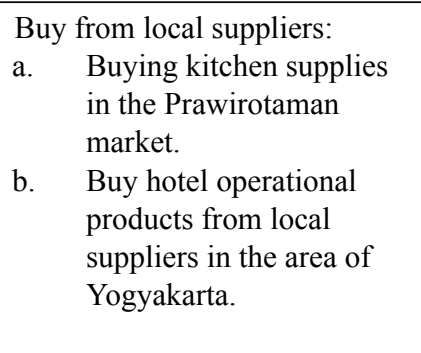 & $\begin{array}{l}\text { Access to local culture: } \\
\text { a. Providing access } \\
\text { for guests to watch } \\
\text { traditional shows in } \\
\text { the local area. }\end{array}$ \\
\hline 3. & 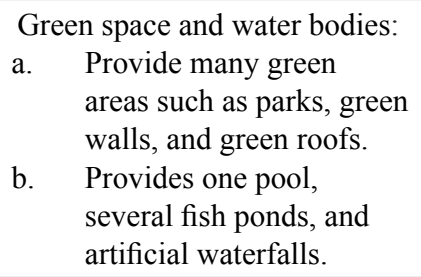 & $\begin{array}{l}\text { Economic cooperation in } \\
\text { services sectors with the local } \\
\text { community: } \\
\text { a. In collaboration with } \\
\text { several tours and travel } \\
\text { services, and vehicle } \\
\text { rental }\end{array}$ & $\begin{array}{l}\text { Serving traditional local } \\
\text { cuisine: } \\
\text { a. Serve some simple } \\
\text { traditional Yogyakarta } \\
\text { food as a breakfast } \\
\text { menu. }\end{array}$ \\
\hline 4. & $\begin{array}{l}\text { Water resource management: } \\
\text { a. Provides many biopori } \\
\text { holes in the open yard }\end{array}$ & & \\
\hline
\end{tabular}

Source: Primary Data, 2019

guests. Third, provide a lot of green areas such as parks, green walls, and green roofs, as well as water surfaces in the form of swimming pools, fish ponds, and artificial waterfalls to reduce surface temperatures. Fourth, provide many biopori holes to store water reserves in the soil.

Concern for the economy of the local community and socio-culture, each found in three practices. The findings of these practices are similar to the implementation of Hotel A, but Hotel B doesn't yet provide services to guests with special needs (disability service). On a mission to improve the economy of the local community, Hotel B recruits fifteen staff who live around the Prawirotaman area for jobs, purchase from local suppliers and craftsmen in the Yogyakarta region, also make a cooperating with various travel and rental business (cars, motorcycles, and bicycles) communitymanaged. While to preserve local culture, Hotel $\mathrm{B}$ has adopted it into the hotel interior, providing services to guests who want to watch traditional shows, and serving a variety of traditional Indonesian dishes for the breakfast menu.

\section{Sustainable Tourism Practices by Hotel C}

Hotel $\mathrm{C}$ is one of the small and minimalist hotels in Prawirotaman Tourist Village, with lower facilities and price rates than the other two sample hotels. The hotel has been operating since 1995 and accommodates guests who looking for cheap rooms. Hotel $\mathrm{C}$ has an area that 
is not too large with fourteen guest rooms. Even though it's just a small hotel, Hotel $\mathrm{C}$ has shown its concern for the environment, economy, and local socio-culture by starting to implement several sustainable tourism practices. One of the sustainable tourism practices implemented by Hotel $\mathrm{C}$ is related to its commitment to providing cheap rooms, among others by limiting the use of air conditioners (AC) and switching to fans for most rooms. The results showed that as many as seven sustainable tourism practices have been found in Hotel C. The seven practices consist of four practices in the environmental field, three practices in the economic field, and one practice in the social-cultural field.

Table 4 shows some simple sustainable tourism practices that have been applied by hotels C. Concern for the environment is found in four practices. First, the minimalist building concept was created by choosing eco-friendly materials such as wood, rattan, and bamboo. Second, reducing energy use by limiting the number of rooms with $\mathrm{AC}$ facilities (four rooms using $\mathrm{AC}$, another room using fans), and ensuring

Table 4: Implementation of sustainable tourism practices in Hotel C

\begin{tabular}{|c|c|c|c|}
\hline No. & Environmental & Economic & Socio-Cultural \\
\hline 1. & $\begin{array}{l}\text { Use eco-friendly building } \\
\text { materials: } \\
\text { a. Using many eco-friendly } \\
\text { building materials such } \\
\text { as wood, rattan, and } \\
\text { bamboo. }\end{array}$ & $\begin{array}{l}\text { Recruit local people for jobs: } \\
\text { a. Recruiting local peoples } \\
\text { to work as housekeeping } \\
\text { and gardeners. }\end{array}$ & $\begin{array}{l}\text { Adoption of the local culture } \\
\text { at the interior and exterior } \\
\text { design: } \\
\text { a. Typical interior } \\
\text { adoption of Java } \\
\text { through the use of } \\
\text { bamboo and rattan } \\
\text { accents. } \\
\text { burniture with } \\
\text { distinctive carvings } \\
\text { and decorative murals } \\
\text { on room walls that } \\
\text { adopt local elements. }\end{array}$ \\
\hline
\end{tabular}

2. Energy-saving culture:
a. Limiting the number of rooms that use $\mathrm{AC}$.
b. Limiting the use of electrical energy during the day.
Buy from local suppliers:
a. Buying kitchen supplies in the prawirotaman market
b. Buy hotel operational products from local suppliers in the area of Yogyakarta.

3. Green space and water bodies:

a. Provide parks and swimming pools as public areas.

b. Utilizing green walls as a planting medium.
Economic cooperation in

services sectors with the local

community:

a. In collaboration with several tours and travel services.

4. Reducing plastics in operational activities:
a. Providing water jug and toiletries dispensers to reduce plastic bottle waste 
all rooms can receive maximum natural lighting and air. Third, utilizing the majority of unbuilt land for the provision of swimming pools and growing various green plants, one of which is in the form of a green wall. Fourth, reduce the use of plastic in operational activities, for example by preferring to use a water jug instead of bottled mineral water for each hotel guest, and using toilet dispensers rather than the toilet in plastic bottles. This fourth practice shows that although classified as a small hotel, Hotel $\mathrm{C}$ has been able to apply one example of a green culture in their workplace.

Concern for the economy of the local community is found in three practices with the implementation that are similar to the two previous hotels. While concern in the sociocultural field is found in only one single practice, that is the adoption of local culture in the interior and exterior design of hotel buildings. This practice is manifested by the use of wood, bamboo, and rattan accents that are thick with traditional Javanese nuances, wooden furniture with distinctive carvings, and various murals on the walls of the rooms that adopt local elements as one of the unique decorations.

\section{Challenges of Sustainable Tourism Practices}

The implementation of operational activities based on sustainable tourism cannot be separated from problems. The hotel business managers stated that the main obstacle in the practice of sustainable tourism in the Prawirotaman Tourist Village to date is the problem of managing water resources and operational costs. As mentioned earlier, the source of water used by hotel business managers comes from well water. Small hotels use shallow or phreatic well water, while large hotels use deep well or artesian water. The high growth of the hotel is directly proportional to the demand for groundwater taken so that it has an impact on the decline in groundwater levels in the local area. Related to this, hoteliers are not unwilling to use water sources from PDAMs, but they are indeed not able to get water from the regional companies, due to damage to the pipeline in the southern part of Yogyakarta City. In the absence of direct action from the government to replace the pipes, some hotels began to take the initiative to make biopori holes and infiltration wells in their open land to store more water reserves.

The high cost needed to support sustainable tourism practices also becomes a serious problem. This problem is in line with the findings of Zaiton et al. (2016) in the results of his research, which showed the financial benefits of adopting sustainable tourism practices are still relatively low compared to the nonfinancial benefits so that it can have an impact on disrupting operational costs and decreasing financial profit. Prawirotaman Tourist Village has long been known as a tourist accommodation offering affordable prices. While the practice of sustainable tourism, especially in environmental aspects, requires a lot of operational costs. Some hotels such as Hotel A and Hotel B chose to increase room rates to support operational costs, while Hotel $\mathrm{C}$ chose to stay at a normal rate because they were worried the number of hotel guests would decrease. The management of Hotel A and Hotel B stated that most tourists support the concept of sustainable tourism in their hotels and agreed to an increase in room rates. The tourists are willing to pay a higher rate for the comfort of staying at their hotel that puts forward the elements of nature and local culture.

\section{Discussion}

Environmental, economic, and social-cultural degradation issues in a tourist accommodation area are the responsibility of tourism businesses peoples, in this study especially hoteliers. Implementation of sustainable tourism by the hoteliers can help minimize these various problems, but there needs to support from various elements such as the government, local communities, and hotel guests. The results showed that the best sustainable tourism practices by hoteliers in the Prawirotaman area were adopted in the economic aspect, with a percentage of $100 \%$ in each practice. This has similarities with the findings of Wijesundara (2017) and Cavagnaro and Gehrels (2009) in 
their research, that the strongest sustainable tourism practices adopted by the hotel business have shown more concern for efforts to improve the economic well-being of local communities, especially in the practice of recruiting local people for jobs, buy from local suppliers, and economic cooperation in services sectors with the local community.

The main challenges in implementing sustainable tourism practices by hoteliers in the Prawirotaman area are limited access to clean water sources and high operational costs. The problem of limited water sources related to the need for supply from the local water supply company (PDAM), needs direct attention from the government. The local government needs to take quick steps to replace or repair PDAM's pipelines in the southern part of Yogyakarta, especially in the Prawirotaman area to avoid a crisis in the decline of the increasingly severe groundwater level. Besides, hoteliers and the local community also need to take initiative by making infiltration wells and biopores in their open areas to help increase groundwater availability.

Implementation of sustainable tourism, especially in the environmental and sociocultural aspects, requires high procurement and maintenance costs. This is following the findings of Sinangjoyo (2013) who revealed that the procurement of energy-efficient equipment in hotels is considered to have a high initial investment value, but the return is not worth it. Related to this problem, Hotel A and Hotel $\mathrm{B}$ have initiated to increase the price of room rates to offset the high operational costs. Some tourists have supported the concept of sustainable tourism in their hotels and accepted the policy. This finding confirms some of the results of previous studies, one of them is Masau and Prideaux (2003), which has suggested that tourists have a willingness to pay higher premiums to enjoy environmentally friendly services. Nevertheless, some studies in other locations show the opposite findings, one of them is Kasim (2004) which in his research has shown that most tourists prefer hotels that are not environmentally friendly, with an emphasis on affordability, personal comfort, and more modern physical attractiveness. The number of tourists who have realized the importance of sustainable tourism is not so much, so the role of the hotel and the surrounding community to promote this concept is very important. The researcher recommends socialization and training efforts for hotel guests, staff, and local communities to work together to build sustainable tourism in the Prawirotaman area.

Research findings and analysis indicate that this research can make a theoretical contribution including information and confirmation for the development of similar research, that currently, the most widely implemented form of implementation by hotels in tourist areas is the initiation or adoption of sustainability in economic aspects. In addition to awareness of the responsibility for the welfare of local communities, the high implementation of this aspect is based on the existence of a mutually beneficial relationship between hoteliers and local peoples. The initiation of sustainable tourism in the economic aspect is considered easier and more profitable compared to the initiation in the environmental and socio-cultural aspects which require high operational costs for the provision and maintenance. However, the concept of sustainable tourism is a unified whole of the three aspects, so that the initiation of sustainability towards environmental and sociocultural aspects must still be done. Teamwork, collaboration, and cooperation between the various parties involved are all we need to overcome the challenges and problems that existing today.

This research contributes practically in communicating to all tourism business peoples in the Prawirotaman area, about the importance of adopting the concept of sustainable tourism as a form of shared responsibility towards the environment and society. This research also contributes to providing some recommendations that are expected to be considered in decision making, as well as being able to encourage the initiation of various parties to begin to move to 
overcome all obstacles in realizing sustainable tourism in the Prawirotaman Tourist Village.

\section{Conclusion}

Fifteen sustainable tourism practices have been found as a research result, consisting of eight environmental aspects, three economic aspects, and four socio-cultural aspects. There is seven best practice that has been generally applied by hoteliers, they use eco-friendly building materials, energy-saving culture, green space, and water bodies availability recruit local people for jobs, buy from local suppliers, economic cooperation in services sectors with the local community, adoption of the local culture at the interior and exterior design. Further analysis confirms that the strongest form of adoption of sustainable tourism is implemented on the economic aspect, which shows high concern for improving the welfare of local communities.

It now appears that many hotels have begun to show their concern by participating and taking their respective roles in the implementation of sustainable tourism practices. Various findings of sustainable tourism practices that have been applied by several sample hotels have helped reduce environmental degradation, encourage the preservation of local culture and wisdom, and improve the welfare of local communities. Judging from the many benefits to the environment and the local community, these findings indicate that hoteliers must continue to improve and promote sustainable tourism practices in their hotels. The government and other related organizations must also take a role in appealing, supporting, and giving more attention to increasing the awareness of tourism businesses about the importance of implementing sustainable tourism.

\section{Acknowledgements}

Authors extend their gratitude to Yogyakarta State University as an institution that has facilitated the development of this manuscript, also to the Prawirotaman Tourist Village community and all hotels who have been willing to be a research sample.

\section{References}

Adam, S. M., Shuib, A., Ramachandrani, S., \& Kunasekaran, P. (2019). Impacts of Ecotourism Development in Tasik Kenyir on The Quality of Life as Perceived by The Local Community. Journal of Sustainability Science and Management, 14(3), 100-109.

Archer, B., Cooper, C., \& Ruhanen, L. (2005). The positive and negative impacts of tourism. Global Tourism.

Ardhiansyah, N., Widyastuti, D. A. R., \& Dita, E. (2019). Perubahan Tata Guna Lahan Kampung Prawirotaman Kota Yogyakarta Sebagai Dampak Keberadaan Kawasan Komersial. ARTEKS Jurnal Teknik Arsitektur, 3(2), 149-157. DOI: http://dx/ doi.org/10.30822/artk.v3i2.163

Badan Pusat Statistik. (2018). Kota Yogyakarta Dalam Angka 2018. Yogyakarta: BPS Kota Yogyakarta

Badan Pusat Statistik. (2018). Kecamatan Mergangsan Dalam Angka 2018. Yogyakarta: BPS Kota Yogyakarta

Bader, E. E. (2005). Sustainable Hotel Business Practices. Journal of Retail \& Leisure Property 5(1).

Bramwell, B., \& Lane, B. (1993). Sustainable Tourism: An Evolving Global Approach. Journal of Sustainable Tourism, 1(1), 1-5.

Cavagnaro, E., \& Gehrels, S.A. (2009). Sweet and Sour Grapes: Implementing Sustainability in the Hospitality Industry-A Case Study. Journal of Culinary Science \& Technology, 7(2-3), 181-195

Costanza, R. \& Patten, B. C. (1995). Defining and predicting sustainability. Ecological Economics.

Cortes, E. C., Azorın, J. F. M, Moliner, J. P., \& Gamero, M. D. L. (2009). Environmental Strategies and Their Impact on Hotel 
Performance. Journal of Sustainable Tourism.

Erdogan, N., \& Baris, E. (2007). Environmental protection programs and conservation practices of hotels in Ankara, Turkey. Tourism Management, 28(2007), 604-614.

Glaesser, D., Kester, J., Paulose, H., Alizadeh, A., \& Valentin, B. (2017). Global travel patterns: an overview. Journal of Travel Medicine.

Goodman, A. (2000). Implementing Sustainability in Service Operations at Scandic Hotels. Interfaces, 30(3), 202214.

Habibullah, M. S., Hajidin, B., Choo, W. C., \& Tan, S. H. (2019). Sustainable Tourism, Deforestation, and Growth: A Case for Malaysia. Journal of Sustainability Science and Management, 14(1), 114-124.

Hall, D., \& Richards, G. (2003). Tourism and sustainable community development. London: Routledge

Kasim, A. (2004). BESR in the Hotel Sector. International Journal of Hospitality \& Tourism Administration, 5(2), 61-83.

Kasimu, A. B, Zaiton, S., \& Hassan, H. (2012). Hotels Involvement in Sustainable Tourism Practices in Klang Valley, Malaysia. International Journal of Economics and Management, 6(1), 21-34

Kementerian Pariwisata dan Ekonomi Kreatif Republik Indonesia \& International Labour Organization. (2012). Rencana Strategis Pariwisata Berkelanjutan dan Green Jobs untuk Indonesia. Jakarta: International Labour Organization (ILO)

Kuhlman, T., \& Farrington, J. (2010). What is Sustainability?. Sustainability, 2(11), 34363448 .

Liu, Z. (2003). Sustainable Tourism Development: A Critique. Journal of Sustainable Tourism, 11(6), 459475. doi:10.1080/09669580308667216
Masau, P., \& Prideaux, B. (2003). Sustainable Tourism: A Role for Kenya's Hotel Industry. Current Issues in Tourism, 6(3), 197-208.

Mbaiwa, J. E. (2003). The socio-economic and environmental impacts of tourism development on the Okavango Delta, north-western Botswana. Journal of Arid Environments, 54(2).

Mensah, J., \& Casadevall, S. R. (Reviewing editor). (2019). Sustainable development: Meaning, history, principles, pillars, and implications for human action: Literature review. Cogent Social Sciences, 5(1), 1-21. DOI: 10.1080/23311886.2019.1653531

Mihalič, T., Žabkar, V., \& Cvelbar, L. K. (2012). A hotel sustainability business model: evidence from Slovenia. Journal of Sustainable Tourism, 20(5), 701719. DOI:10.1080/09669582.2011.632092

Niedziolka, I. (2012). Sustainable Tourism Development. Regional Formation and Development Studies.

Owen, R .E., Wittand, S. F., \& Gammon, S. (1993). Sustainable tourism development in Wales. Tourism Management

Pearce, A. R., \& Vanegas, J. A. (2002). Defining sustainability for built environment systems: an operational framework. International Journal of Environmental Technology and Management, 2(1/2/3), 94.

Setiawan, B., Rijanta, \& Baiquni, M. (2017). Sustainable Tourism Development: the Adaptation and Resilience of the Rural Communities in (the Tourist Villages of) Karimunjawa, Central Java. Forum Geografi, 31(2).

Siew, K. M., Ramachandran, S., Kunasekaran, P., Herman, S., Fatin, N., Shuib, A., \& Prabhakaran, S., (2017). Performance Indicators of Energy Security and Sustainable Tourism in Enhancing Service Innovation of Island Tourism. World Applied Sciences Journal, 35, 27-32.

Sinangjoyo, N. J. (2013). Green Hotel Sebagai Daya Saing Suatu Destinasi: Studi Kasus 
Pada Industri Hotel Berbintang di Wilayah Yogyakarta. Jurnal Nasional Pariwisata, $5(2)$.

Stefãnica, M., \& Butnaru, G. I. (2015). Research on Tourists' Perception of the Relationship between Tourism and Environment. Procedia Economics and Finance, 20, 595600.

Swarbrooke, J., \& Page, S. J. (2012.) Development and management of visitor attractions. Routledge.

Taechasriprasert, S., Phungrussami, H., \& Usubharatana, P. (2019). Socio-EcoEfficiency Score for Business Sustainability Development and Evaluation. Journal of Sustainability Science and Management, 14(2), 143-155.

Timothy, D.J. (1999). Participatory Planning A View Tourism in Indonesia. Annals of Tourism Research, 26(2).
UNTWO. (2019). International Tourism Highlight 2019 Edition.

Wijesundara, C.N.R. (2017). Adoption of Sustainable Tourism Practices by Hotel Operators in Deep South of Sri Lanka. International Journal of Research in Management Science and Technology.

Wirakusuma, R.M. (2014). Analisis Karakter Wisatawan Mancanegara Terhadap Fasilitas Wisata Kawasan Prawirotaman. Jurnal Pariwisata, 1(1).

Zaiton, S., Herman, M.A.S., \& Hassan, H. (2016). Sustainable Tourism Practices Among Hotels in Malaysia: Financial and Non-Financial Benefits. Journal of Sustainability Science and Management, 11(1), 73-81. 